\title{
Effect of Neuroactive Peptides on Labeled 5-Hydroxytryptamine Release from Rat Spinal Slices in Vitro
}

\author{
Huei-Yann TSAI*, Sadaaki MAEDA, Katsuya IWATSUBO \\ and Reizo INOKI \\ Department of Pharmacology, Faculty of Dentistry, Osaka University, Osaka 565, Japan \\ *Department of Pharmacology, China Medical College, Taichung 400, Taiwan
}

Accepted May 4, 1984

\begin{abstract}
Effects of neuroactive peptides on the release of labeled 5-hydroxytryptamine (5-HT) from preloaded rat spinal cord slices were investigated. The 5 - HT release was significantly stimulated by somatostatin $(10-50 \mu \mathrm{M})$ and substance $\mathrm{P}(10-50 \mu \mathrm{M})$, but not by neurotensin $(50 \mu \mathrm{M}), \beta$-endorphin $(30 \mu \mathrm{M})$ and methionine-enkephalin (met-enk) $(100 \mu \mathrm{M})$. Somatostatin-stimulated 5-HT release was markedly inhibited by $\gamma$-aminobutyric acid (GABA) $(30 \mu \mathrm{M})$, but not by baclofen $(30 \mu \mathrm{M})$ and met-enk $(100 \mu \mathrm{M})$. Substance P-stimulated 5-HT release was strongly inhibited by GABA $(30 \mu \mathrm{M})$ and baclofen $(30 \mu \mathrm{M})$, but not by met-enk $(100 \mu \mathrm{M})$. High concentrations $(20 \mathrm{mM})$ of potassium also stimulated $5-\mathrm{HT}$ release. The high potassium-stimulated $5-\mathrm{HT}$ release was not affected by GABA $(30 \mu \mathrm{M})$ and met-enk $(100 \mu \mathrm{M})$. These results suggested further evidence on the important role of somatostatin and substance $P$ as modulators of serotonergic neurones.
\end{abstract}

The 5-HT-containing neurones, which mainly originate from the nucleus raphe magnus and project to the spinal trigeminal sensory nucleus have been defined by biochemical $(1,2)$ and histochemical $(3,4)$ investigations. This projection plays an important role in the mechanism of antinociception (5). Furthermore, immunohistochemical studies have shown the existence of some neuropeptides such as substance $P$, somatostatin, neurotensin and met-enk in the trigeminal sensory nucleus (6-8).

The present study was attempted to investigate effects of endogenous neuropeptides on the release of $5-\mathrm{HT}$ from spinal cord slices including the trigeminal sensory nucleus in vitro in order to determine the relationship between neuropeptides and 5$\mathrm{HT}$ in the pain control mechanism.

\section{Materials and Methods}

Male Sprague-Dawley rats, weighing 200$300 \mathrm{~g}$, were decapitated, and the spinal cord from the obex to the 5 th cervical vertebra including the trigeminal sensory nucleus was rapidly removed and sliced at ca. $0.3 \mathrm{~mm}$ thickness. The slices were immersed in cooled modified Krebs-bicarbonate solution (composition in $\mathrm{mM}: \mathrm{NaCl}, 120 ; \mathrm{KCl}, 5$; $\mathrm{NaHCO}_{3}, 15 ; \mathrm{NaH}_{2} \mathrm{PO}_{4}, 1.5 ; \mathrm{CaCl}_{2}, 1.5$; $\mathrm{MgSO}_{4}, 1.0$; glucose, 10; saturated with $95 \%$ $\left.\mathrm{O}_{2}-5 \% \mathrm{CO}_{2}, \mathrm{pH}, 7.4\right)$.

The slices (15-20 mg) were incubated with $10 \mathrm{nM}^{3} \mathrm{H}-5-\mathrm{HT}$ (S.A. $32.1 \mathrm{Ci} / \mathrm{mmole}$ ) for $30 \mathrm{~min}$ at $37^{\circ} \mathrm{C}$. After incubation, the slices were washed 5 times with the Krebsbicarbonate solution containing $7.5 \times 10^{-5} \mathrm{M}$ pargyline to prevent the metabolism of ${ }^{3} \mathrm{H}-5$ $\mathrm{HT}$. Then, the slices were transferred to a small glass superfusion chamber and were superfused with the Krebs-bicarbonate solution containing $7.5 \times 10^{-5} \mathrm{M}$ pargyline at $37^{\circ} \mathrm{C}$ at a rate of $0.25 \mathrm{ml} / \mathrm{min}$. After $20 \mathrm{~min}$ from the start, the superfusion samples were continuously collected at $5 \mathrm{~min}$ intervals. Stimulation was induced by 5 min application of $20 \mathrm{mM}$ potassium chloride into the superfusion medium or $25 \mathrm{~min}$ application of various neuropeptides. GABA and baclofen were added to the medium from the beginning 
of the perfusion, respectively. The radioactivity in each fraction was measured by a liquid scintillation spectrometer (Aloka, LSC673). It was checked in another experiment using a Sephadex G-10 column that approximately $30 \%$ of the total radioactivities measured in the perfusate was due to 5HIAA, a metabolite of $5-\mathrm{HT}$ and others. All results were presented in terms of the percent deviation of dpm from the base line. The base line estimated following the stimulation was obtained by extrapolating the stable curve from the preceding 6th sample in a similar manner to that described by Yaksh and Yamamura (9). Statistical analysis of the differences was carried out in paired experiments by Student's $t$-test.

The following drugs were used: 5-[1,2$\left.{ }^{3} \mathrm{H}(\mathrm{N})\right)$ ]-hydroxytryptamine creatine sulfate (New England Nuclear), somatostatin, substance $P$, methionine-enkephalin, neurotensin (Japan Peptide Research Company), $r$ aminobutyric acid (Wako Chemical Company), baclofen (Sigma).

\section{Results}

Potassium-stimulated 5-HT release: Twenty $\mathrm{mM} \mathrm{KCl}$ could stimulate $5-\mathrm{HT}$ release, while calcium deprivation by removing $\mathrm{Ca}$ from the medium plus addition of $0.1 \mathrm{mM}$ EDTA significantly reduced the $\mathrm{K}$-stimulation of the 5-HT release (Fig. 1). Application of $30 \mu \mathrm{M}$ of GABA, an inhibitory neurotrans- mitter in the spinal cord $(10,11)$, in the medium failed to influence the $\mathrm{K}$-stimulated $5-\mathrm{HT}$ release (not shown).

Effect of somatostatin on 5-HT release: Application of $10-50 \mu \mathrm{M}$ somatostatin to the medium produced a marked increase in the $5-\mathrm{HT}$ release (Fig. 2). This effect was not suppressed under the condition of $\mathrm{Ca}$ deprivation. Potassium-stimulated 5-HT release was not affected by the application of 10-50 $\mu \mathrm{M}$ somatostatin. The somatostatinstimulated 5-HT release was significantly

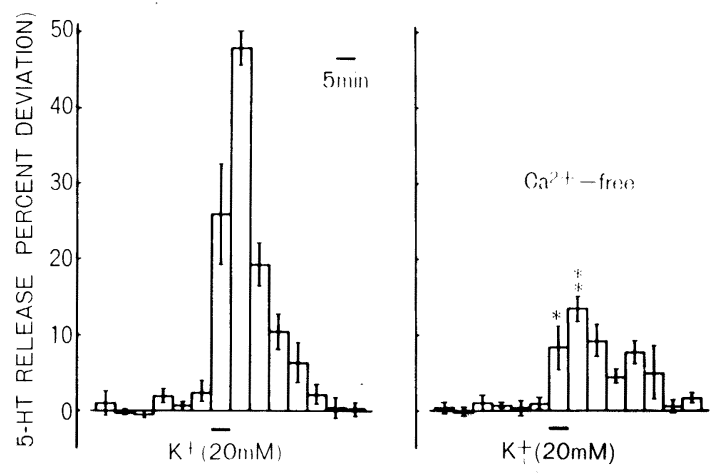

Fig. 1. Release of ${ }^{3} \mathrm{H}-5-\mathrm{HT}$ from rat spinal slices: Release was evoked by a $5 \mathrm{~min}$ application of $20 \mathrm{mM}$ potassium chloride (left fig.) or by $20 \mathrm{mM}$ potassium chloride in a calcium-free medium containing $0.1 \mathrm{mM}$ EGTA (right fig.). Each column is the mean \pm S.E.M. Asterisk represents statistically significant defference from the value of the control in the same period: ${ }^{*} \mathrm{P}<0.05,{ }^{* *} \mathrm{P}<0.01$.
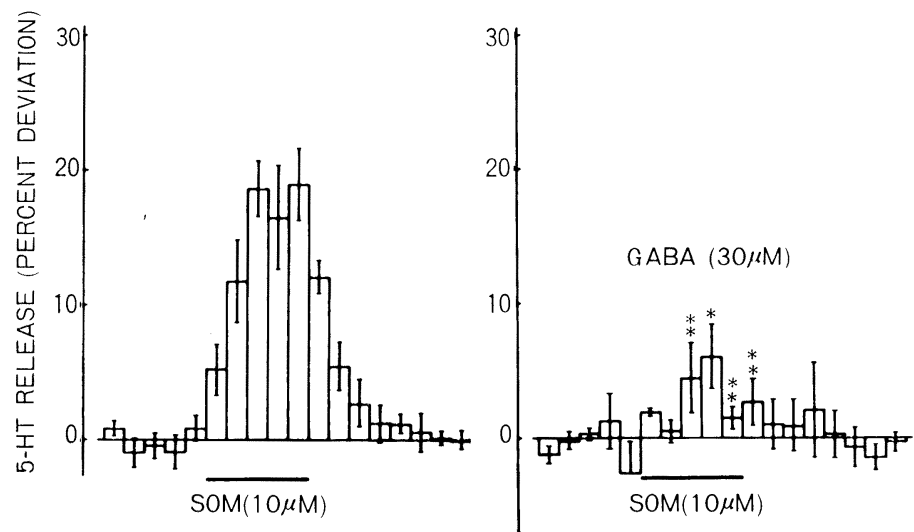

Fig. 2. Effect of somatostatin on ${ }^{3} \mathrm{H}-5-\mathrm{HT}$ release: Release was evoked by $10 \mu \mathrm{M}$ somatostatin (left fig.) or by $10 \mu \mathrm{M}$ somatostatin in the presence of $30 \mu \mathrm{M}$ GABA (right fig.). Other explanations are the same as given in Fig. 1. SOM; Somatostatin. 

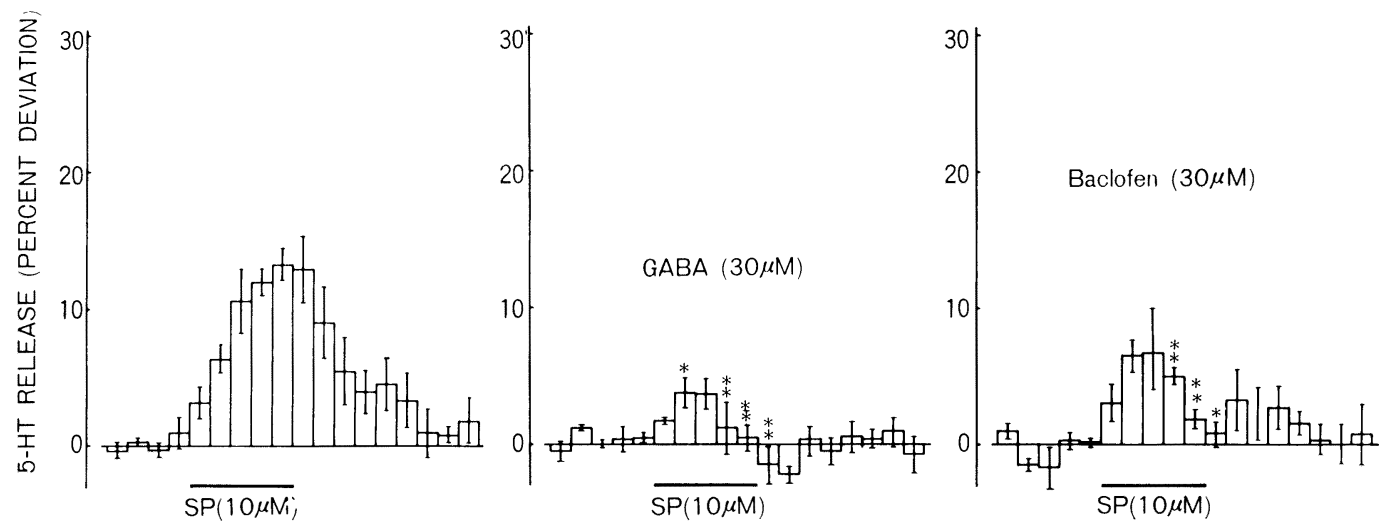

Fig. 3. Effect of substance $\mathrm{P}$ on ${ }^{3} \mathrm{H}-5-\mathrm{HT}$ release: Release was evoked by $10 \mu \mathrm{M}$ substance $\mathrm{P}$ (left fig.), by $10 \mu \mathrm{M}$ substance $\mathrm{P}$ in the presence of $30 \mu \mathrm{M}$ GABA (center fig.), or by $10 \mu \mathrm{M}$ substance $\mathrm{P}$ in the presence of $30 \mu \mathrm{M}$ baclofen (right fig.). Refer to the explanation in Fig. 1. SP: Substance P.

inhibited by $30 \mu \mathrm{M}$ GABA (Fig. 2), but not by $30 \mu \mathrm{M}$ baclofen and $100 \mu \mathrm{M}$ met-enk (not shown).

Effect of substance $P$ on 5-HT release: Application of $10-50 \mu \mathrm{M}$ substance $\mathrm{P}$ in the medium significantly stimulated $5-\mathrm{HT}$ release (Fig. 3), but it did not affect $\mathrm{K}$ stimulated $5-\mathrm{HT}$ release. The stimulatory action of substance $P$ was not suppressed under the condition of $\mathrm{Ca}$ deprivation. The substance $P$-stimulated $5-\mathrm{HT}$ release was significantly inhibited by either $30 \mu \mathrm{M}$ GABA or $30 \mu \mathrm{M}$ baclofen (Fig. 3 ).

The uptake of ${ }^{3} \mathrm{H}-5-\mathrm{HT}$ into the slices was not influenced by both $10 \mu \mathrm{M}$ somatostatin and $10 \mu \mathrm{M}$ substance $\mathrm{P}$.

Application of $50 \mu \mathrm{M}$ neurotensin or 100 $\mu \mathrm{M}$ met-enk to the medium did not alter 5-HT release (not shown).

\section{Discussion}

The present study was designed to investigate the interaction between $5-\mathrm{HT}$ and neuropeptides in the spinal cord in vitro.

Substance $P$ has been considered as a neurotransmitter of pain in the primary afferent fibers $(12,13)$, and the possible interaction between substance $P$ and metenk was reported $(6,14)$. It was also reported that somatostatin was contained in the primary afferent fibers (7), and it potentiated the norepinephrine release from rat cortex slices (15) and stimulated the acetylcholine release from rat hippocampal synaptosomes
(16). In the present study, it was found that both somatostatin and substance $\mathrm{P}$ stimulated the ${ }^{3} \mathrm{H}-5-\mathrm{HT}$ release from rat spinal cord slices. The $5-\mathrm{HT}$ release induced by substance $P$ was already observed in the raphe nucleus (17), substantia nigra (18) and trigeminal nucleus (19). These reports were consistent with our present results.

Calcium-dependent 5-HT release evoked by high potassium from rat spinal trigeminal nucleus had been reported (19). Our data also agreed with this.

GABA has been suggested as an inhibitory transmitter in the central nervous system. The present study showed that GABA appeared to have no effect on the potassium-stimulated ${ }^{3} \mathrm{H}-5-\mathrm{HT}$ release, while ${ }^{3} \mathrm{H}-5-\mathrm{HT}$ release stimulated by somatostatin or substance $P$ was significantly inhibited by GABA. These results indicate that effects of the these two neuropeptides on the 5-HT release are not due to a direct action on the terminals of 5 -HT-containing neurones. Furthermore, baclofen, which was reported to be a substance $P$ antagonist in the central nervous system (20), inhibited the ${ }^{3} \mathrm{H}-5-\mathrm{HT}$ release stimulated by substance $P$, but not by somatostatin. This result may suggest that the site of action of both peptides on 5-HT release is different.

Enkephalin is also suggested to be an inhibitory transmitter found in the small interneurones in the marginal layer of the trigeminal caudal nucleus and lamina $\mathrm{I}-\mathrm{II}$ in 
the spinal cord (21). The action of this substance has been suggested to be an inhibition of the release of substance $P$, pain transmitter of the primary afferent, from the primary $\mathrm{C}$ fiber (14). In this study, met-enk had no effect on ${ }^{3} \mathrm{H}-5-\mathrm{HT}$ release stimulated by high potassium, somatostatin and substance $P$. Accordingly, it probably suggests that met-enk is scarcely concerned with the inhibition of $5-\mathrm{HT}$ release.

In conclusion, the present study gave further evidence suggesting the important role of somatostatin and substance $P$ as modulators of serotonergic neurones.

\section{References}

1 Zivin, J.A., Reid, J.L., Saavedra, J.M. and Kopin, I.J.: Quantitative localization of biogenic amines in the spinal cord. Brain Res. 99, 293301 (1975)

2 Saavedra, J.M.: Distribution of serotonin and synthesizing enzymes in discrete areas of the brain. Fed. Proc. 36, 2134-2141 (1977)

3 Oliveras, J.L., Bourgoin, S., Hery, F., Besson, J.M. and Hamon, M.: The topographical distribution of serotonergic terminals in the spinal cord of the cat: Biochemical mapping by the combined use of microdissection and microassay procedures. Brain Res. 138, 393-406 (1977)

4 Segu, L. and Calas, A.: Topographical distribution of serotoninergic terminals in the spinal cord of the cat: Quantitative radioautographic studies. Brain Res. 153, 449-464 (1978)

5 Fields, H.L. and Basbaum, A.I.: Anatomy and physiology of a descending pain control system. Adv. Pain Res. Ther. 3, 427-440 (1979)

6 Hökfelt, T., Ljungdahl, Å., Terenius, L., Elde, R. and Nilsson, G.: Immunohistochemical analysis of peptide pathways possibly related to pain and analgesia; Enkephalin and substance $P$. Proc. Natl. Acad. Sci. U.S.A, 74, 3081-3085 (1977)

7 Hökfelt, T., Elde, R., Johansson, O., Luft, R., Nilsson, G. and Arimura, A.: Immunohistochemical evidence for separate populations of somatostatin-containing and substance P-containing primary afferent neurons in the rat. Neuroscience 1, 131-136 (1976)

8 Uhl, G.R., Kuhar, M.J. and Snyder, S.H.: Neurotensin: Immunohistochemical localization in rat central nervous system. Proc. Natl. Acad. Sci. U.S.A. 74, 4059-4063 (1977)
9 Yaksh, T.L. and Yamamura, H.I.: Blockade by morphine of acetylcholine release from the caudate nucleus in the mid pontine pretrigeminal cat. Brain Res. 83, 520-524 (1957)

10 Barker, J.L. and Nicoll, R.A.: Gamma-aminobutyric acid: Role in primary afferent depolarization. Science 176, 1043-1045 (1972)

11 Eccles, J.C., Schmidt, R. and Willis, W.D.: Presynaptic inhibition of the spinal monosynaptic reflex pathway. J. Physiol. (Lond.) 161, 282-297 (1962)

12 Piercey, M.F., Dobry, P.J.K., Schroeder, L.A. and Einspahr, E.J.: Behaviour evidence that substance $P$ may be a spinal cord sensory neurotransmitter. Brain Res. 210, 407-412 (1981)

13 Yaksh, T.L., Farb, D.H., Leeman, S.E. and Jessell, T.M.: Intrathecal capsaicin depletes substance $P$ in the rat spinal cord and prolonged thermal analgesia. Science 206, 481-483 (1979)

14 Jessell, T.M. and Iversen, L.L.: Opiate analgesics inhibit substance $P$ release from rat trigeminal nucleus. Nature 268, 549-551 (1977)

15 Tsujimoto, A. and Tanaka, S.: Stimulatory effect of somatostatin on norepinephrine release from rat brain cortex slices. Life Sci. 28, 903-910 (1981)

16 Nemeth, E.F. and Cooper, J.R.: Effect of somatostatin on acetylcholine release from rat hippocampal synaptosomes. Brain Res. 165, 166-170 (1979)

17 Kerwin, R.W. and Pycock, C.J.: The effect of some putative neurotransmitters on the release of 5-hydroxytryptamine and $\gamma$-aminobutyric acid from slices of the rat mid-brain raphe area. Neuroscience 4, 1359-1365 (1979)

18 Reubi, J.C., Emson, P.C., Jessell, T.M. and Iversen, L.L.: Effects of GABA, dopamine and substance $P$ on the release of newly synthesized ${ }^{3} \mathrm{H}-5$-hydroxytryptamine from rat substantia nigra in vitro. Naunyn Schmiedebergs Arch. 304, 271-275 (1978)

19 Reubi, J.C.: In vitro release of $5-{ }^{3} \mathrm{H}$-hydroxytryptamine from rat spinal trigeminal nucleus. Neurosci. Lett. 16, 263-267 (1980)

20 Saito, K., Konishi, S. and Otsuka, M.: Antagonism between lioresal and substance $P$ in rat spinal cord. Brain Res. 97, 177-180 (1975)

21 Simantov, R., Kuhar, M.J., Uhl, G.R. and Snyder, S.H.: Opioid peptide enkephalin: Immunohistochemical mapping in rat central nervous system. Proc. Natl. Acad. Sci. U.S.A. 74, 2167-2171 (1977) 